\title{
Advanced Innovative Solutions for Final Design in Terms of Energy Sustainability of Nearly/Net Zero Energy Buildings (nZEB)
}

\author{
Domenico Mazzeo *(D) and Giuseppe Oliveti \\ Department of Mechanical, Energy and Management Engineering (DIMEG), University of Calabria, \\ 87036 Rende, Italy; giuseppe.oliveti@unical.it \\ * Correspondence: domenico.mazzeo@unical.it; Tel.: +39-0984-494841
}

Received: 6 December 2020; Accepted: 8 December 2020; Published: 12 December 2020

\section{Overview}

EU Directives have reinforced both studies and research for the development of innovative technological solutions to improve building energy performance and to achieve a reduction in total energy consumption, with benefits in terms of reducing greenhouse gas emissions, as well as in economic terms [1-3].

To realize nearly/net Zero Energy Buildings (nZEB), sustainability has become a significant aspect and has been integrated into the design, construction and operation of buildings. For this reason, innovative sustainable technological solutions have been proposed to improve the thermal performance of the building envelope and to increase the use of energy from renewable sources. For example, they concern: (i) the stratigraphy of walls and the windows [4-7], through the use of phase change materials [8-12], new silica aerogel-based insulating [13,14], green vertical system [15,16] and green [17-19] and cool roofs [20,21], etc.; (ii) the integration of systems that employ renewable heat sources, namely solar radiation, wind, geothermal, etc. [22,23].

The aim of sustainable buildings is the ability to integrate and adapt buildings to environmental factors and climate conditions and convert them for space and comfort. The selection of proper sustainable building materials or technologies is an important issue in the building design. A correct selection should lead to high durability, energy efficiency, recyclability, maintainability, economic saving, and use of local materials to reduce the environmental impact of construction. In this context, there is a lack of common understanding in the field, and this Special Issue aims to collect contributions regarding the evaluation of the sustainability of nZEB. Overall, 30 original articles were submitted to this Special Issue, of which 15 high-quality papers successfully overcame the single-blind peer-review process and are summarized in this Editorial.

\section{A Short Review of the Contributions to This Special Issue}

Various topics were numerically and experimentally developed in this Special Issue. The study of the energy performance of some innovative window and opaque walls in new, existing, or laboratory prototypes was addressed worldwide in the context of achievement of Nearly Zero Energy Buildings (nZEB) target. For the numerical analyses, new and standard procedures were implemented in new simulation tools or existing ones. The main indices considered are the building heating and the cooling energy demand, and indoor comfort. The studies involved different climatic conditions, such as Italy, China, United Kingdom, South Korea, Norway, Poland, and Chile.

As regards the opaque envelope, six articles studied the impact of implementing passive solutions, such as phase change materials (PCM), green roofs, dynamic insulations, high-performance 
insulation materials and sunshades, flexible canopies and Prefabricated Straw Bale Construction (PSBL), on building energy performance and saving [24-29].

Lee et al. [24] used Esp-r simulation software to evaluate the heating and cooling load reduction and Predicted Mean Vote (PMV) for human comfort adopting multi variable PCM types as the building wall composite in a modernized Korean Hanok. They concluded that PCM helps reduce energy consumption also of $53.1 \%$. Piro et al. [25] analyzed the hydraulics and energy performances of a real scale model of an extensive green roof at the University of Calabria (Italy) in Mediterranean area This study confirms that green roofs contribute to reducing thermal fluctuation on the external and internal surfaces, thereby lowering the energy consumption for the maintenance of indoor comfort conditions. From the point of view of stormwater management, a green roof system can significantly reduce stormwater runoff generation in terms of runoff volume reduction and peak attenuation. Gruner and Matusiak [26] tested dynamic insulation which has the task to potentially reduce heat loss through highly insulating windows in the Nordic climate. The new system was both numerically simulated using THERM and tested in full-scale in a Hot-box apparatus in a steady-state condition at the laboratory of SINTEF Building and Infrastructure in Trondheim, Norway. The results are promising and showed improvement of the thermal performance of a poorly insulated window. J.-H. Kim et al. [27] attempted to quantify the consumers' willingness to pay for the governmental pilot net-zero energy apartments (NZEA), which use high-performance insulation materials and sunshades to minimize the use of household cooling and heating energy. Kwon et al. [28] analyzed the environmental role of a flexible canopy as a microclimate modifier in balancing indoor energy demands and outdoor thermal comfort using several environmental software packages (Ecotect, Rayman, WinAir, DaySim, and EDSL TAS). The results showed that the flexible canopy played a crucial role in reducing indoor energy demands (heating and electricity for lighting) and increasing outdoor thermal comfort under the canopy area. To analyze the performance of canopies, simulations using different transparencies and orientations were performed for flexible and fixed canopies in London, Manchester, and Glasgow, having different climates. The flexible canopy with higher transparency helped increase outdoor thermal comfort in Glasgow, while one with lower transparency showed better performance during summer in London. Yin et al. [29] presented an analysis of Prefabricated Straw Bale Construction (PSBC) in residential buildings to reduce energy consumption in this building type in severe cold regions and cold regions in northern China. The results show that the buildings with PSBC reduce both heating and cooling energy uses, as well as heating intensities, across all climatic regions in northern China, compared to the domestic buildings with conventional constructions.

Instead, two articles aimed to study the thermal performance of enhanced window systems [30,31]. Oh et al. [30] compared the impact of the recently developed electrochromic glazing technology on load reduction by comparing it with the double-glazing and shading devices that are available commercially for high-rise residential buildings in Korea. Using EnergyPlus software, electrochromic glazing was found to be more effective for reducing the cooling loads compared with the heating loads. Koo et al. [31] searched for a solution to the high-cost problem of the existing double-skin façade system by proposing a double-skin façade window with a smaller ventilated air cavity. Windows were installed in chambers of an artificial solar lab and real building test cells. The artificial solar lab test results showed that the solar heat gain coefficient can be lowered through ventilation by $28 \%$ to $52.9 \%$. In addition, the cumulative power consumption was reduced by around $3 \%$ through ventilation in the air cavity.

The other four articles applied and compared different common international standards related to energy and comfort performance indices [32-35]. Y. Kim et al. [32] calculated energy requirements that satisfied the insulation standards, for each of the Korean regional climate conditions, of the Building Energy Conservation Code (BECC), a standard of mandatory energy-related minimum requirements to specify mandatory and energy performance indices of energy-saving design. For this issue, they used the methodology of ISO 13790. Finally, this study derived that a return of investment can be achieved in 10 years, which was determined through comprehensive economic 
feasibility analysis due to strengthening insulation performances, proving the rationalization of the legal strengthening. The same authors presented a methodology and process to establish a mandatory policy of zero-energy buildings (ZEBs) in Korea [33]. A self-sufficiency rate was also proposed to strengthen the passive standard of the buildings as well as to encourage new and renewable energy production. The overall scope is to define ZEBs following the technical and economic circumstances in Korea and to describe the study methodology for establishing the mandatory policies and criteria to this end. It also aims to investigate the characteristics of certified buildings through case analyses on zero-energy-certified buildings. Piasecki et al. [34] contributed to the actual state of knowledge as a "small and specific scale" validation of the existing thermal comfort model. They compared the thermal comfort measurement method based on the ISO-Fanger model with the actual comfort results obtained by the panelists in the experimental building of the Małopolska Laboratory of Energy Efficient Building in Cracow, Poland. Pérez-Fargallo et al. [35] analyzed the standards recommended by Chile's Construction with Sustainability Criteria for the building of housing, in a social housing prototype located in the region of the Bio-Bio and analyzed under two international standards-the ASHRAE 55-2017 and the EN 15251:2007 adaptive comfort models-and one national standard, the Chilean ECCS. Results in numerical terms can be different depending on the standard, but all of them will point in the same direction.

Other topics treated in this Special Issue are the visual comfort while investigating energy consumption [36], innovative air-conditioning systems [37] and monitoring system [38] in nZEBs. Zhang et al. [36] presented an optimization method and industrial internet of things (IIoT) technology that is proposed for nearly zero energy buildings (nZEB), providing a comfortable visual environment by only utilizing natural light while improving its induced indoor air conditioner energy consumption. Five modes were defined and investigated for different applications, and the best visual comfort and energy consumption conditions were identified. Chuah et al. [37] experimentally studied an integrated dedicated outdoor air system (IDOAS), which integrates the enthalpy exchange and outdoor air cooling into a unitary system, to investigate a mean of saving air-conditioning energy while maintaining good indoor air quality. The test results show that about $44 \%$ of the energy needed to condition the outdoor air can be saved and the cooling coefficient of performance (COP) was improved by about $46 \%$. Huh et al. [38] describe a monitoring solution, a power line communication (PLC) and Android Application, for the management of decrepit buildings or apartments. This platform technology for smart metering is proposed as a PLC-based monitoring system in zero energy building management. This technology allows a system operator or an operation center to monitor, calculate, or manage power use remotely through the existing power line so that individual suppliers will be able to grasp the present condition of power use and respond to any unexpected incidents. The authors expect that the proposed platform technology will be one of the promising technologies for sustainable building, since its uninterrupted power usage monitoring and remote power control/management functions will be quite useful for economizing power with convenience.

This Special Issue may help bridge the gap between sustainability and improvement of the building energy efficiency. Other Special Issues on the topic should be organized periodically to update the state of the art.

Author Contributions: Conceptualization, D.M.; writing—original draft preparation, D.M.; writing—review and editing, D.M.; visualization, D.M and G.O. Both authors have read and agreed to the published version of the manuscript.

Funding: This research received no external funding.

Acknowledgments: The Editors would like to thank all the researchers for their high-quality papers, the reviewers for the suggestions provided in the scheduled deadlines, the editorial team of Sustainability and MDPI Branch Office.

Conflicts of Interest: The authors declare no conflict of interest. 


\section{References}

1. Directive 2010/31/EU. European Parliament and of the Council of 19 May 2010 on the energy performance of buildings (recast). Off. J. Eur. Union 2010, 13-35, L153.

2. Directive 2012/27/EU. European Parliament and of the Council of 25 October 2012 on energy efficiency, amending Directives 2009/125/EC and 2010/30/EU and repealing directives 2004/8/EC and 2006/32/EC. Off. J. Eur. Union 2012, 1-56, L315/1.

3. Directive 2018/844/EU. European Parliament and of the Council of 30 May 2018 Amending Directive 2010/31/EU on the Energy Performance of Buildings and Directive 2012/27/EU on Energy Efficiency. 2018. Available online: https://eur-lex.europa.eu/legal-content/EN/TXT/?uri=uriserv\%3AOJ.L_.2018.156.01.0075. 01.ENG (accessed on 11 December 2020).

4. Mazzeo, D.; Kontoleon, K.J. The role of inclination and orientation of different building roof typologies on indoor and outdoor environment thermal comfort in Italy and Greece. Sustain. Cities Soc. 2020, 60, 102111. [CrossRef]

5. Mazzeo, D.; Oliveti, G.; Arcuri, N. Mapping of the seasonal dynamic properties of building walls in actual periodic conditions and effects produced by solar radiation incident on the outer and inner surfaces of the wall. Appl. Therm. Eng. 2016, 102, 1157-1174. [CrossRef]

6. Congedo, P.M.; Baglivo, C.; Centonze, G. Walls comparative evaluation for the thermal performance improvement of low-rise residential buildings in warm Mediterranean climate. J. Build. Eng. 2020, 28, 101059. [CrossRef]

7. Zhao, J.; Du, Y. Multi-objective optimization design for windows and shading configuration considering energy consumption and thermal comfort: A case study for office building in different climatic regions of China. Sol. Energy 2020, 206, 997-1017. [CrossRef]

8. Li, D.; Wu, Y.; Wang, B.; Liu, C.; Arıc1, M. Optical and thermal performance of glazing units containing PCM in buildings: A review. Constr. Build. Mater. 2020, 233, 117327. [CrossRef]

9. Elarga, H.; Fantucci, S.; Serra, V.; Zecchin, R.; Benini, E. Experimental and numerical analyses on thermal performance of different typologies of PCMs integrated in the roof space. Energy Build. 2017, 150, 546-557. [CrossRef]

10. Mazzeo, D.; Matera, N.; Cornaro, C.; Oliveti, G.; Romagnoni, P.; De Santoli, L. EnergyPlus, IDA ICE and TRNSYS predictive simulation accuracy for building thermal behaviour evaluation by using an experimental campaign in solar test boxes with and without a PCM module. Energy Build. 2020, 212, 109812. [CrossRef]

11. Mazzeo, D.; Oliveti, G.; de Gracia, A.; Coma, J.; Solé, A.; Cabeza, L.F. Experimental validation of the exact analytical solution to the steady periodic heat transfer problem in a PCM layer. Energy 2017, 140-141, 1131-1147. [CrossRef]

12. Mazzeo, D.; Oliveti, G. Thermal field and heat storage in a cyclic phase change process caused by several moving melting and solidification interfaces in the layer. Int. J. Therm. Sci. 2018, 129, 462-488. [CrossRef]

13. Zeng, Q.; Mao, T.; Li, H.; Peng, Y. Thermally insulating lightweight cement-based composites incorporating glass beads and nano-silica aerogels for sustainably energy-saving buildings. Energy Build. 2018, 174, 97-110. [CrossRef]

14. Ibrahim, M.; Biwole, P.H.; Wurtz, E.; Achard, P. A study on the thermal performance of exterior walls covered with a recently patented silica-aerogel-based insulating coating. Build. Environ. 2014, 81, 112-122. [CrossRef]

15. Pérez, G.; Coma, J.; Martorell, I.; Cabeza, L.F. Vertical Greenery Systems (VGS) for energy saving in buildings: A review. Renew. Sustain. Energy Rev. 2014, 39, 139-165. [CrossRef]

16. Coma, J.; Pérez, G.; de Gracia, A.; Burés, S.; Urrestarazu, M.; Cabeza, L.F. Vertical greenery systems for energy savings in buildings: A comparative study between green walls and green facades. Build. Environ. 2017, 111, 228-237. [CrossRef]

17. Palermo, S.A.; Turco, M.; Principato, F.; Piro, P. Hydrological effectiveness of an extensive green roof in Mediterranean climate. Water 2019, 11, 1378. [CrossRef]

18. Mazzeo, D.; Bevilacqua, P.; De Simone, M.; Arcuri, N. A new simulation tool for the evaluation of energy performances of green roofs. Build. Simul. Appl. 2015, 313-321. Available online: http://www.ibpsa.org/ proceedings/BSA2015/9788860460745_39.pdf (accessed on 11 December 2020).

19. Pirouz, B.; Palermo, S.A.; Maiolo, M.; Arcuri, N.; Piro, P. Decreasing Water Footprint of Electricity and Heat by Extensive Green Roofs: Case of Southern Italy. Sustainability 2020, 12, 10178. [CrossRef] 
20. Saafi, K.; Daouas, N. A life-cycle cost analysis for an optimum combination of cool coating and thermal insulation of residential building roofs in Tunisia. Energy 2018, 152, 925-938. [CrossRef]

21. Fang, H.; Zhao, D.; Yuan, J.; Aili, A.; Yin, X.; Yang, R.; Tan, G. Performance evaluation of a metamaterial-based new cool roof using improved Roof Thermal Transfer Value model. Appl. Energy 2019, 248, 589-599. [CrossRef]

22. Mazzeo, D.; Matera, N.; De Luca, P.; Baglivo, C.; Congedo, P.M.; Oliveti, G. Worldwide geographical mapping and optimization of stand-alone and grid-connected hybrid renewable system techno-economic performance across Köppen-Geiger climates. Appl. Energy 2020, 276, 115507. [CrossRef]

23. Li, K.; Liu, C.; Jiang, S.; Chen, Y. Review on hybrid geothermal and solar power systems. J. Clean. Prod. 2020, 250, 119481. [CrossRef]

24. Lee, J.; Park, J. Phase Change Material (PCM) Application in a Modernized Korean Traditional House (Hanok). Sustainability 2018, 10, 948. [CrossRef]

25. Piro, P.; Carbone, M.; De Simone, M.; Maiolo, M.; Bevilacqua, P.; Arcuri, N. Energy and Hydraulic Performance of a Vegetated Roof in Sub-Mediterranean Climate. Sustainability 2018, 10, 3473. [CrossRef]

26. Gruner, M.; Matusiak, B. A Novel Dynamic Insulation System for Windows. Sustainability 2018, $10,2907$. [CrossRef]

27. Kim, J.; Kim, H.; Yoo, S. Consumers' Willingness to Pay for Net-Zero Energy Apartment in South Korea. Sustainability 2018, 10, 1564. [CrossRef]

28. Kwon, C.; Lee, K.; Cho, S. Numerical Study of Balancing between Indoor Building Energy and Outdoor Thermal Comfort with a Flexible Building Element. Sustainability 2019, 11, 6654. [CrossRef]

29. Yin, X.; Dong, Q.; Zhou, S.; Yu, J.; Huang, L.; Sun, C. Energy-Saving Potential of Applying Prefabricated Straw Bale Construction (PSBC) in Domestic Buildings in Northern China. Sustainability 2020, 12, 3464. [CrossRef]

30. Oh, M.; Tae, S.; Hwang, S. Analysis of Heating and Cooling Loads of Electrochromic Glazing in High-Rise Residential Buildings in South Korea. Sustainability 2018, 10, 1121. [CrossRef]

31. Koo, B.; Lee, K.; An, Y.; Lee, K. Solar Heat Gain Reduction of Ventilated Double Skin Windows without a Shading Device. Sustainability 2018, 10, 64. [CrossRef]

32. Kim, Y.; Yu, K. Study on the Certification Policy of Zero-Energy Buildings in Korea. Sustainability 2020, 12, 5172. [CrossRef]

33. Kim, Y.; Yu, K. Study on Policy Marking of Passive Level Insulation Standards for Non-Residential Buildings in South Korea. Sustainability 2018, 10, 2554. [CrossRef]

34. Piasecki, M.; Fedorczak-Cisak, M.; Furtak, M.; Biskupski, J. Experimental Confirmation of the Reliability of Fanger's Thermal Comfort Model-Case Study of a Near-Zero Energy Building (NZEB) Office Building. Sustainability 2019, 11, 2461. [CrossRef]

35. Pérez-Fargallo, A.; Rubio-Bellido, C.; Pulido-Arcas, J.; Gallego-Maya, I.; Guevara-García, F. Influence of Adaptive Comfort Models on Energy Improvement for Housing in Cold Areas. Sustainability 2018, 10, 859. [CrossRef]

36. Zhang, Y.; Zhong, Y.; Gong, Y.; Zheng, L. The Optimization of Visual Comfort and Energy Consumption Induced by Natural Light Based on PSO. Sustainability 2019, 11, 49. [CrossRef]

37. Chuah, Y.; Yang, J. A Integrated Dedicated Outdoor Air System to Optimize Energy Saving. Sustainability 2020, 12, 1051. [CrossRef]

38. Huh, J.; Park, J. Decrepit Building Monitoring Solution for Zero Energy Building Management Using PLC and Android Application. Sustainability 2020, 12, 1993. [CrossRef]

Publisher's Note: MDPI stays neutral with regard to jurisdictional claims in published maps and institutional affiliations.

(C) 2020 by the authors. Licensee MDPI, Basel, Switzerland. This article is an open access article distributed under the terms and conditions of the Creative Commons Attribution (CC BY) license (http://creativecommons.org/licenses/by/4.0/). 